\title{
Collagen types I and III in giant papillae of vernal keratoconjunctivitis
}

\author{
Andrea Leonardi, Giovanni Abatangelo, Roberta Cortivo, Antonio G Secchi
}

\begin{abstract}
Aims-The objective of this study was to investigate alterations in conjunctival collagen and proteoglycans in the conjunctival giant papillae of patients with vernal keratoconjunctivitis (VKC). Methods-Tissue samples from tarsal giant papillae of seven eyes from five patients with VKC, and five tarsal conjunctival samples from five normal patients were obtained. Tissues were processed and stained with haematoxylin and eosin, Van Gieson, trichromic Mallory, toluidine blue, Alcian blue, and alkaline Giemsa. Collagen extraction was performed in acetic acid and pepsin, total collagen was quantified using hydroxyproline levels, and collagen types I and III were analysed by gel electrophoresis (SDS-PAGE). Proteoglycans were quantified using uronic acid levels.

Results-Histological evaluation showed a significant increase of mast cells in the epithelium $\left(0 / \mathrm{mm}^{2} v 147 / \mathrm{mm}^{2}, \mathbf{p}<0.01\right)$ and in the stroma $\left(5 \cdot 1 / \mathrm{mm}^{2} v 80 / \mathrm{mm}^{2}\right.$, $p<0 \cdot 01)$ of VKC patients. Collagen fibres were thicker and arranged irregularly, with the total amount significantly increased. Owing to an increased percentage of type III collagen, the ratio of collagen types I to III was decreased. Proteoglycans were also reduced in VKC samples.

Conclusion-The well known morphological abnormalities observed in VKC correspond to alterations in the ratio between collagens and proteoglycans, and between different types of collagen. The greatly increased number of mast cells found in these tissues suggests an active role for these cells in the abnormal connective tissue metabolism observed in VKC.

(Br f Ophthalmol 1995; 79: 482-485)
\end{abstract}

University of Padova, Italy

Institute of

Ophthalmology

A Leonardi

A G Secchi

Institute of Histology

G Abatangelo

R Cortivo

Correspondence to: Andrea Leonardi, $\mathrm{MD}$, Via Palesa, 27, 35128 Padova, Italy.

Accepted for publication

5 December 1994
Vernal keratoconjunctivitis (VKC) is a recurrent inflammatory disease characterised by tarsal conjunctival giant papillae resulting from a hyperplasia of conjunctival connective tissue. ${ }^{1-3}$ An abnormal organisation of the three dimensional network of conjunctival collagen fibres in VKC may be the result of an increased amount of total collagen relative to other matrix components, such as the proteoglycans, or of a modification in the ratio between the fibre forming collagens, type I and type III. This metabolic alteration, inducing either an excessive production or a decreased catabolism of the extracellular matrix, may be an effect of many proinflammatory mediators, cytokines, or both released by resident conjunctival cells and by the numerous inflammatory cell types infiltrating the tissue. ${ }^{4}$

The purpose of this study was to investigate, from both a histological and biochemical perspective, the nature of the giant papillae in vernal conjunctivitis. Histologically, various specific histochemical stains were used for the illustration of the extracellular matrix and various cell types. Biochemically, the total amount of collagen and proteoglycans was identified, in addition to the relative proportions of fibre forming collagens, type I and III.

\section{Materials and methods}

Five patients (seven eyes) participated in this study: three males and two female, ranging in age from 11 to 20 years. Five tarsal conjunctival biopsies were obtained from an additional five normal, age matched subjects for controls. Informed consent was obtained from all patients or their parents. Conjunctival biopsies were obtained under local anaesthesia with topical bupivacaine $0.4 \%$ and/or local injection of carbacaine 3\%. Each biopsy was divided into two sections, one fixed in formalin for histological analysis, and the second, snap frozen for biochemical analyses.

Formalin fixed and paraffin blocked specimens were cut in $5 \mu \mathrm{m}$ sections and stained with the following stains: haematoxylin and eosin, Van Gieson, trichromic Mallory, toluidine blue ( $\mathrm{pH} \mathrm{2)}$, Alcian blue ( $\mathrm{pH} \mathrm{2)}$, and alkaline Giemsa. Sections stained with alkaline Giemsa were used for cell counts at high power magnification $(\times 1000)$. Mast cells, neutrophils, eosinophils, basophils, lymphocytes, and plasma cells were identified according to the criteria given by Allansmith. ${ }^{5}$ Fibroblasts were recognised as fusiform elongated cells between the collagen bundles. Cells were counted in the epithelium and in the substantia propria of five consecutive high power fields of a giant papillae section, and expressed as number of cells $/ \mathrm{mm}^{2}$.

After being defrosted, the frozen tissues were placed for 30 minutes in a solution containing $0.02 \mathrm{M}$ EDTA, sodium chloride 4.5 M, $1 \mathrm{mM}$ phenylmethylsulphonyl fluoride, and $2 \mathrm{mM} \mathrm{N}$-ethyl maleimide at $0^{\circ} \mathrm{C}$. Samples were washed, dried, weighed, and then homogenised in $0.5 \mathrm{M}$ acetic acid for 4 days at $4^{\circ} \mathrm{C}$. Suspensions were centrifuged for 45 minutes at $30000 \mathrm{rpm}$ and the supernatants decanted. Pellet residues were digested with $0.5 \mathrm{M}$ acetic acid and pepsin overnight at $4^{\circ} \mathrm{C}$, and then centrifuged. The supernatants were pooled with the first extraction. Precipitates 


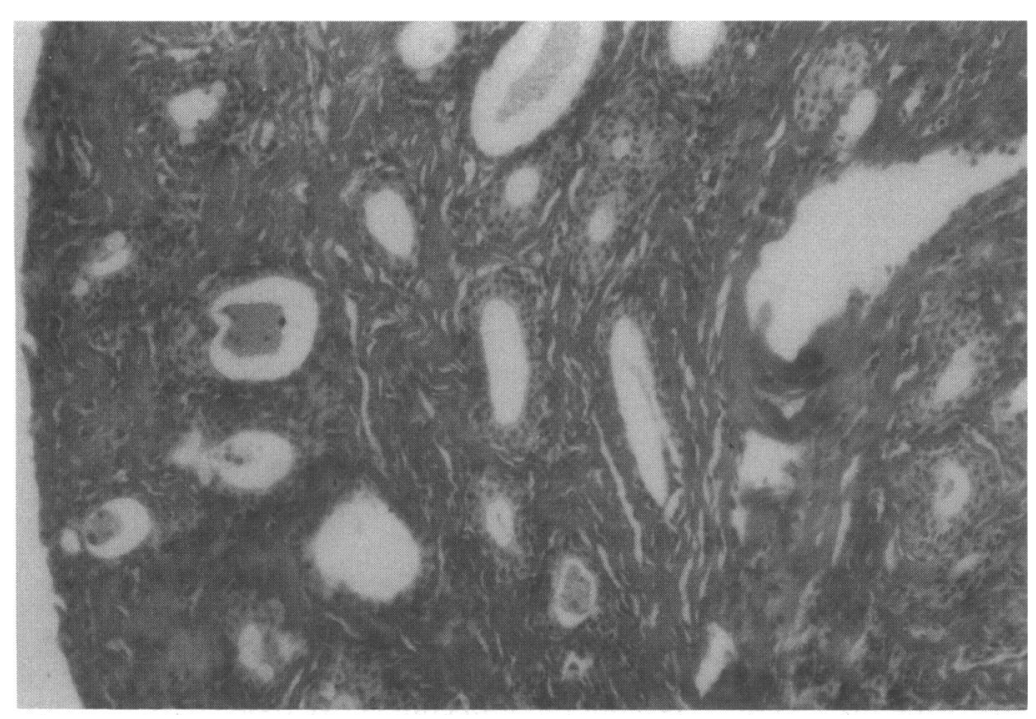

Figure 1 Conjunctival section of vernal keratoconjunctivitis giant papillae stained with van Gieson (X136). Note the thickness of the collagen fibres and their irregular disposition. Note also the epithelial ingrowths.

(collagens) were obtained after dialysis from the pooled, digested supernatants, which were pelleted by centrifugation, dissolved in $0.5 \mathrm{M}$ acetic acid, dialysed against $0.5 \mathrm{M}$ acetic acid at $4^{\circ} \mathrm{C}$, and lyophilised.

The total amount of collagen was determined by the quantity of hydroxyproline, since this amino acid represents $12-14 \%$ of the molecule. One $\mathrm{ml}$ of the sample was incubated for 10 minutes at $40^{\circ} \mathrm{C}$ with $1 \mathrm{ml}$ copper sulphate, $1 \mathrm{ml}$ sodium hydroxide, and $1 \mathrm{ml}$ hydrogen peroxide. After cooling, $4 \mathrm{ml}$ sulphuric acid and $2 \mathrm{ml}$ of para-dimethylaminobenzaldehyde were added to the sample and it was incubated at $70^{\circ} \mathrm{C}$ for 16 minutes. After cooling, samples were read by spectrophotometry (Kontron Uvikon 930) at a wavelength of $555 \mu \mathrm{m}$.

The quantity of proteoglycans was determined by the amount of uronic acid present in samples as described by Woessner. ${ }^{6}$

The collagen extracted with pepsin and acetic acid was then analysed by gel electrophoresis on an SDS-polyacrylamide slab gel in $3.6 \mathrm{mM}$ urea. As a standard, collagens I and III (Sigma, St Louis, MI, USA) were used. After electrophoresis, gels were stained with Coomassie blue R-250 and then treated with methanol/acetic acid for 1 hour. The relative

Table 1 Median number of cells $/ \mathrm{mm}^{2}$ in the conjunctival epithelium

\begin{tabular}{lllllllll}
\hline & Lymph & PC & Neu & Eos & Bas & MC & Fib & Total \\
\hline Normal & 135 & - & 65 & - & - & - & - & 200 \\
VK & 65 & 8 & 74 & 48 & 2 & 147 & - & 344 \\
p Value & NS & NS & NS & 0.05 & NS & 0.01 & & NS
\end{tabular}

Lymph=lymphocytes; $\mathrm{PC}=$ plasma cell; $\mathrm{Neu}=$ neutrophil; Eos=eosinophil; Bas=basophil; MC =mast cell; Fib = fibroblast; VK=vernal keratoconjunctivitis.

Table 2 Median number of cells $/ \mathrm{mm}^{2}$ in the conjunctival stroma

\begin{tabular}{llllllllr}
\hline & Lymph & $P C$ & Neu & Eos & Bas & MC & Fib & Total \\
\hline Normal & 384 & 340 & 20 & - & - & 5 & 115 & 864 \\
VK & 325 & 202 & 34 & 81 & 8 & 80 & 355 & 1085 \\
p Value & NS & NS & NS & 0.01 & 0.05 & 0.01 & 0.01 & 0.05
\end{tabular}

Lymph =lymphocytes; PC=plasma cell; Neu=neutrophil; Eos=eosinophil; Bas=basophil; MC=mast cell; $F i b=$ fibroblast; $V K=$ vernal keratoconjunctivitis. quantity of collagen protein bands was measured by an automatic laser densitometer (Molecular Dynamics). The automatic integration of the areas corresponding to each peak of the optical density profile gave the percentage of $\alpha 1$ and $\alpha 2$ chains of collagens I and III.

Statistical analyses for cell counts were performed using the Student's $t$ test. Results are listed as the mean (SEM). For statistical significance, the assigned $\mathrm{p}$ value was $\leqslant 0 \cdot 05$.

\section{Results}

Morphologically, the normal conjunctiva contained a delicate pattern of collagen fine fibres arranged in layers parallel to the epithelial surface. In tissues taken from the giant papillae of patients with vernal keratoconjunctivitis, collagen fibres, stained with both Van Gieson and Azan Mallory, appeared thicker, irregularly arranged and without a definite layer or direction (Fig 1). Epithelial expansions and ingrowths into the subjacent fibrous tissues formed glandular-like processes and contained numerous goblet cells. The density of goblet cells, highlighted by the metachromatic stain, toluidine blue, appeared higher than in the normal epithelium.

Cell counts in the epithelium of VKC samples showed a significantly increased number of eosinophils and mast cells (Table 1). In the conjunctival stroma, the number of eosinophils $\left(81 \mathrm{~mm}^{2}\right)$ and basophils $\left(8 \mathrm{~mm}^{2}\right)$ was significantly increased $(p<0.01$ and $\mathrm{p}<0.05$, respectively) compared with no cells present in normal stroma. Connective tissue mast cells were also significantly increased in VKC $\left(80 \mathrm{~mm}^{2}\right)$ compared with controls $\left(5 \mathrm{~mm}^{2}, \mathrm{p}<0.01\right)$. The numbers of fibroblasts and fibroblast-like cells in the stroma were significantly increased from $115 \mathrm{~mm}^{2}$ in normals to $355 \mathrm{~mm}^{2}$ in the giant papillae of patients with VKC $(p<0.01)$ (Table 2). The total numbers of cells in the stroma were also significantly increased $(p<0.05)$ in VKC compared with normal tissues.

When the biochemical profile of tarsal conjunctival tissue from VKC patients was compared with that of normal conjunctival tissue, the total amount of collagen expressed in \% dry weight was increased in every sample (Table 3), with a mean total collagen of $3.1 \%$ in VKC tissues compared with $1.1 \%$ in control tissues. Conversely, the total amount of proteoglycans was decreased in all VKC samples, with a mean of $0.6 \%$ compared with $1.0 \%$ in control samples.

Gel electrophoresis after pepsin treatment of conjunctival tissues was used to identify $\alpha 1$ (I), $\alpha 2$ (I), and $\alpha 1$ (III) chains (Fig 2). In normal tissues, collagen was $80 \%$ type I and $20 \%$ type III, with a ratio of $4: 1$. In VKC tissues, collagen was $68 \cdot 4 \%$ type I (range $61-73$ ) and $31.5 \%$ type III (range $27-39$ ), with a ratio of 2:1 (Table 3).

\section{Discussion}

Vernal keratoconjunctivitis is a chronic 
Table 3 Quantity of collagen and proteoglycans (\% dry weight) in conjunctival tissue

\begin{tabular}{lllll}
\hline Sample population & Collagen & Proteoglycans & Type I collagen & Type III collagen \\
\hline $\begin{array}{l}\text { Normal tissues: } \\
\text { Mean (n=5) }\end{array}$ & $1 \cdot 1$ & 1.0 & & \\
VK tissues (individual samples): & & 80 & 20 \\
1 & $3 \cdot 1$ & 0.6 & 68 & 32 \\
2 & 5.4 & 0.4 & 61 & 39 \\
3 & 1.5 & 0.7 & 72 & 28 \\
4 & 1.6 & 0.9 & 73 & 33 \\
5 & 3.2 & 0.5 & 67 & 32 \\
6 & 3.8 & 0.7 & 68 & 31.7 \\
7 & 3.3 & 0.6 & 69 & \\
\hline
\end{tabular}

$\mathrm{VK}=$ vernal keratoconjunctivitis.

immunological inflammation originating from both IgE and cellular mediated mechanisms ${ }^{7}$ in addition to a mucosal hyperreaction to nonspecific stimuli. ${ }^{8}$ Results of the present study confirm that giant papillae have a morphologically altered collagen structure. This abnormality was observed in association with increases in mast cell, basophil, eosinophil, and fibroblast populations. The collagen fibres appeared thicker and irregularly arranged around epithelial ingrowths. Biochemically, it was demonstrated that the total amount of collagen was increased three times in VKC compared with controls, while the percentage of proteoglycans was reduced. Since the number of fibroblasts was also increased in the stromal conjunctiva of giant papillae, it is possible that these cells, activated by growth and/or stimulating factors released by inflammatory cells, effectively increased the production of collagen.

Collagen type I is the most abundant collagen in the body and tends to be deposited in less distensible tissues. It consists of two $\alpha 1$ (I) chains and one $\alpha$ (I) chain in a triple helix configuration. Type III collagen is comprised of three $\alpha 1$ (III) chains combined in a triple helix and is closely associated with type I in a wide variety of tissues. Type III constitutes a high percentage of total collagen during development, and plays a major role in modulating tissue structure and function in health and disease. ${ }^{9}$ It was found increased in corneal wound healing ${ }^{10}$ and in bronchial subepithelial

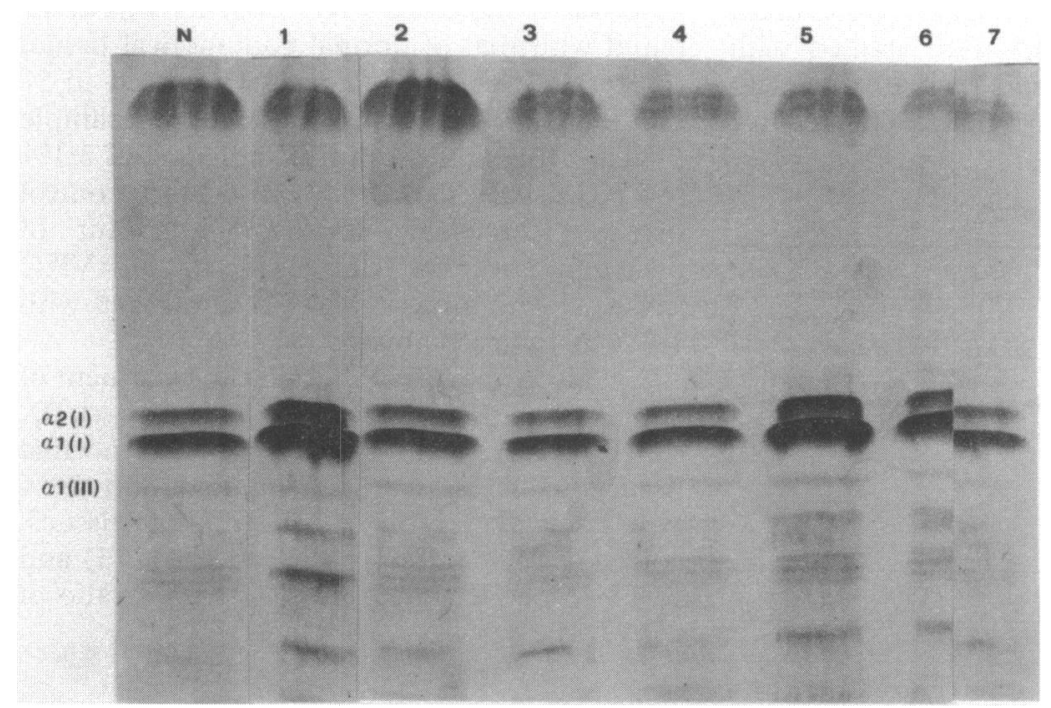

Figure 2 Gel electrophoresis of collagen extracted from a normal subject $(N)$ and from patients with vernal keratoconjunctivitis $\alpha 1$ chains and $\alpha 2$ chains of type I collagen and $\alpha 1$ chains of type III collagen were measured by densitometry after gel staining. fibrosis of asthmatic patients. ${ }^{11}$ In the present study, an increase in type III collagen was noted in the giant papillae of VKC patients, altering the proportion of fibre forming collagens from the $4: 1$ ratio of type I: type III collagen found in normal conjunctiva to a ratio of 2:1 in diseased tissue. These abnormal proportions of type III and I collagen and proteoglycans are perhaps the biochemical basis of the morphological changes long noted in the conjunctival connective tissue of VKC patients.

How fibroblast induced synthesis of collagen and non-collagen protein is influenced by immunologically mediated inflammation has not been previously investigated in VKC. According to previous studies, in the recurrent/chronic allergic response of VKC, eosinophils and connective tissue mast cells are the two populations of cells most increased in conjunctival tissues. An increased number of mast cells has been observed in association with fibrosis in many other chronic inflammatory disorders, suggesting that mast cell mediators have a direct effect on fibroblasts and, thus, have the potential to affect the connective tissue microenvironment. Mast cells are known to be capable of activating collagenase ${ }^{12}$ and both mast cells and eosinophils have tropic effects on fibroblasts. ${ }^{13} 14$ Furthermore, fibroblasts have been shown to induce mast cell differentiation towards that of the connective tissue phenotype, the subclass primary increased in VKC. ${ }^{1516}$ A fibroblast stimulating role of basophils, notably present in VKC tissues, is also possible. Allansmith has proposed in various studies that, in addition to anaphylactic atopy, an immunological mechanism similar to a cutaneous basophil hypersensitivity contributes to the pathogenesis of VKC. ${ }^{17}$

Histamine is the most prominent inflammatory mediator released by mast cells and basophils. Always increased in tears of patients with vernal conjunctivitis, ${ }^{18} 19$ histamine has been shown to stimulate fibroblast growth and enhance collagen synthesis. ${ }^{20} 21$ Other potential contributors to the remodelling of connective tissue are inflammatory cell derived proteolytic enzymes and heparin proteoglycan, the major matrix component of mast cell connective tissue. ${ }^{22} 23$

In conclusion, this study highlighted the occurrence of an extensive deposition of collagen in the conjunctiva of vernal keratoconjunctivitis patients. This collagen overproduction certainly cannot be considered a unique phenomenon to VKC, but rather a common finding in chronically inflamed tissue. However, if the disease specific stimuli for its hypersynthesis were identified, one facet of the pathophysiology of VKC would be defined. The origin of this defect may be directly related to excessive fibroblast activity, due to: (1) a continuous stimulation of fibroblasts by the increased number of activated mast cells, eosinophils and basophils with a subsequent increase in cytokines and growth factors; (2) a lack of down regulatory mechanisms; or (3) an innate hyperactivity of upper conjunctival 
fibroblasts. The expansion of inflammatory cell populations, the presence of abnormal bands of fibrillar collagen and the modified proportions of the constituents of extracellular matrix suggest an active role of allergic inflammation in connective tissue physiology. Further studies involving the immunohistochemistry of VKC conjunctival tissues and fibroblast cultures from giant papillae are under way to help elucidate the genesis of collagen overgrowth in VKC.

1 Allansmith MR. The eye and immunology. St Louis: Mosby, 1982 .

2 Buckley RJ. Vernal keratoconjunctivitis. Int Ophthalmol Clinics 1988; 28: 303-8.

3 Easty DL, Birkenshaw M, Merrett T, Merrett J, Entwhistle $C$, Amer B. Immunological investigations in vernal eye disease. Trans Ophthalmol Soc UK 1980; 100: 98-107.

4 Freundlich B, Bomalski JS, Neilson E, Jimenez SA. Regulation of fibroblast proliferation and collagen synthesis by cytokines. Immunol Today 1986; 7: 303-7.

5 Allansmith MR, Greiner JV, Baird RS. Number of inflammatory cells in the normal conjunctiva. Am $₹$ Ophthalmol 1978; 86: 250-9.

6 Woessner JFJ. Determination of hydroxyproline in tissue and protein samples containing small proportion of the amino acid. Arch Biochem Biophys 1961; 93 440-7.

7 Maggi E, Biswas P, Del Prete G, Parronchi P, Macchia D, Simonelli C, et al. Accumulation of Th-2-like helper T cells in the conjunctiva of patients with vernal conjunctivitis. $\mathcal{F}$ Immunol 1991; 146: 1169-74.

8 Bonini S, Bonini S, Todini V, Schiavone M, Centofanti M, Allansmith MR, et al. Conjunctival hyperresponsiveness Allansmith MR, et al. Conjunctival hyperresponsiveness to ocular histamine challenge in patients with vernal
junctivitis. $\mathcal{F}$ Allergy Clin Immunol 1992; 89: 103-7.

9 Uitto J. Molecular pathology of collagen. In: Abatangelo G Davidson JM, eds. Cutaneous development, aging and repair. Padova: Fidia Research Series, Liviana Press, 1989; 18: 9-29.

10 Cintron C, Hong B-S, Covington HI, Macarak EJ. Heterogeneity of collagens in rabbit cornea: type III collagen. Invest Ophthalmol Vis Sci 1988; 29: 767-75.

11 Roche WR, Beasley R, Williams JW, Holgate ST. Subepithelial fibrosis in the bronchi of asthmatics. Lancet 1989; ii: $520-4$.

12 Pillarisetti V, Rao S, Friedman MM, Atkins FM, Metcalfe DD. Phagocytosis of mast cell granules by cultured fibroblasts. F Immunol 1983; 130: 341-9.

13 Lee Choi K, Claman HN. Mast cells, fibroblasts, and fibrosis. New clues to the riddle of mast cells. Immunol Res 1987; 6: 145-52.

14 Spry CJ, Davies J, Tai PC. Eosinophils and endomyocardial fibrosis. Contrib Microbiol Immunol 1987; 7: 212-7.

15 Morgan SJ, Williams JH, Walls AF, Church MK, Holgate ST, McGill JI. Mast cell number and staining characteristics in the normal and allergic conjunctiva. $f$ Allergy Clin Immunol 1991; 87: 111-6.

16 Irani AM, Butrus SI, Tabbara KF, Schwartz LB. Human conjunctival mast cell: distribution of MCT and MCTC in vernal and giant papillary conjunctivitis. $\mathcal{f}$ Allergy Clin Immunol 1990; 86: 34-40.

17 Allansmith MR, Cornell-Bell AH, Baird RS, Bloch $\mathrm{KJ}$, Askenase PW. Conjunctival basophil hypersensitivity in the guinea pig. 7 Allergy Clin Immunol 1986; 78: 919-27.

18 Abelson MB, Baird RS, Allansmith NR Tear histamine levels in vernal conjunctivitis and other ocular inflammations. Ophthalmology 1980; 87: 812-4.

19 Abelson MB, Leonardi A, Smith LM, Fregona IA, Secchi AG. Histaminase activity in vernal keratoconjunctivitis. Invest Ophthalmol Vis Sci 1994; 35 (ARVO): 1290.

20 Jordana $M$, Befus AD, Newhouse MT, Bienenstock J, Gaudie J. Effect of histamine on proliferation of normal human adult lung fibroblasts. Thorax 1988; 43: 552-8.

21 Hatamochi A, Fujiwara K, Ueki $H$. Effects of histamine on collagen synthesis by cultured fibroblasts derived from guinea pig skin. Arch Derm Res 1985; 277: 60-4.

22 Azikhan RG, Azikhan JC, Zetter BR, Folkman J. Mast cell heparin stimulates migration of capillary endothelial cells in vitro. $\mathcal{F}$ Exp Med 1980; 152: 931-44.

23 Birkedal-Hansen H, Cobb CM, Taylor RE, Fullmer HM. Activation of fibroblast procollagenase by mast cell proteases. Biochim Biophys Acta 1976; 438: 273-86. 